\title{
S GMLをベースとした法制業務の総合システム化と 行政改革への展望
}

\author{
1998.10.29 \\ 西村健 \\ (NKシステム・リサーチ)
}

1.はしめに

自治体における一基幹業務への「SGML」の導入事例を紹介し、その今日的意義につ いて若干の知見をまとめてみた。

筆者は、神奈川県に長年勤務し、多様な業務を経験したが、自治体の法制業務（自治体 の規範である条例・規則等を制定改廃する業務）の要查を担当する「文書課」に在職した 際、自治体における代表的な基幹業務である法制業務のすべての段階を、そっくりとシス テム統合する『法規事務支援システム』を企画し、その開発に携わった。

『法規事務支援システム』の開発のねらいは、大局的に表現すれば、次の二項目に集約 されよう。

第一 : ペーパーワーク・リダクションによるリエンジニアリング効果

第ニ : コンテキスト自動復元によるアカウンタビリティー効果

第一に関して、説明すれば、法制業務は、大变多くの手続きとルールの䙉合体であり (本論末の「法規事務の流れ図」を参照)、法令文書の内容の構造性が敩密かつ複雑なこ とからもたらされる文章表現上の困難さという際だった性筫によって、審查を含め、多く のトライアルアンドエラーを綝り返すこととなり、そのため、文書の書き直しと文書の受 け渡しの頻度とが高まることとなる。このような煩雑な「ペーパーワーク」をシステム統 合することによって、作業工数を大幅にリダクションし、リエンジニアリングをもたらす ことを目指す。

第二に関して、説明すれば、法制業務の制定、改正、廃止の内訳は、そのほとんどが既 に存在している規則等の「改正業務」であり、改正の手法の特殊性により、担当者などこ く一部の関係者を除き、一般人にはなかなかその文意を理解できにくい。改正の過程にお いても、また、改正例規の公布後においても、職員はもとより、地域住民の誰であっても、 当該規範の内容理解が必要なとき、容易にその意味内容を理解できることが求められる。 元来、自治立法権は地域住民のために存在するものだからである。そこで、改正後の文章 のコンテキストを復元し、文面を読みとれ、その意味内容をたどれる状態を実現する。こ れにより、行政改革の主要なコンセプトである住民への重要なアカウンタビリティー実装 の一環に资する。

以下、本システムの概要にふれた後、自治体のドキュメント管理における「SGML」 のもたらす機能性と意義について考察する。

\section{2.法制業弱㓳理の流九とシステム化による業務改革}

法制業務は、䙉数のセクションの関係する多くの担当者が参加して実施され（本論末の 「法規事務の流れ図」を参照）、その業務段階は、次の表（《図表一1》）に主要な項目 を揭げるように、褚雑にやり取りされつつ進行する。この表では、直接の担当者の例示に 
とどめているが、実際には、上司によるチェックや承認など、その業務処理の流れは大変 䙉雑なものであり、ことに条例の場合には、議会への提案と議決を経なければならないた め、さらに褓雑な手続きと関係する職員により、業務全体の処理に要する手間は相当な負 担を要している。

\begin{tabular}{|c|c|}
\hline 《図表一1》《法制執務の業務段階》 & 《関係する担当者の例示》 \\
\hline 1）法律改正等の改正等原因情報の収集·分析 & 該当事業課 $A \cdot B \cdot C$ \\
\hline 2）改正等を要する条例・規則等の検索及び検討 & $A \cdot B \cdot C$ \\
\hline 3）改正等方針の合意形成及び改正等要綱の作成 & $A \cdot B \cdot C$ \\
\hline 4) 改正等文案の作成 & $A \cdot B \cdot C$ \\
\hline 5）新旧対照表の作成 & $A \cdot B \cdot C$ \\
\hline 6) 法令審查 & 文書課 $D \cdot E$ \\
\hline 7) 原棎の修正 & $A \cdot B \cdot C$ \\
\hline 8）起案·決裁 & $A \cdot B \cdot C \cdot D \cdot E$ \\
\hline 9）公報編集·発行 & 文書課 $D \cdot E \cdot F$ \\
\hline 10）例規集の更新 & . \\
\hline
\end{tabular}

このような業務実態からもたらされる問題性は、概ね次の表（《図表一 $2 》) の$ 左闌に 掲げるように整理できる。

そこで、法制業務の全体を『統合文書処理システム』化し、条例・規則等のすべての自 治体内の規範を「SGML」によりデータベース化した。

このシステムは、条例・規則の制定改廃を行う法制執務の一連の作業を、その開始から、 改正案文の作成、法令審查、決裁プロセス、公報発行、例規データベースの更新に至るま で統合処理するもので、SGML化された条例・規則等の例規のドキュメント・データベ 一スを中心として、関係するすべての業務段階を通じてコンカレントにシステム連携を図 っている。

『統合文書処理システム』化により、先に指摘した「従来の法制業務の問題性」は、表 (《図表ー 2 》)の右欄に掲げるようなイノベーティブな解決効果が見込まれる。

《图表ー2》く「法規事務支援システム」による “統合文書処理効果”の想定 $>$

\begin{tabular}{|c|c|}
\hline $\begin{array}{llllll}\text { 現 } & \text { 状 } & \text { 問 } & \text { 題 } & \text { 状 } \\
\end{array}$ & イノベーション \\
\hline A) 紙べースの作業によるムダ & ペーパーワーク・リダクション \\
\hline 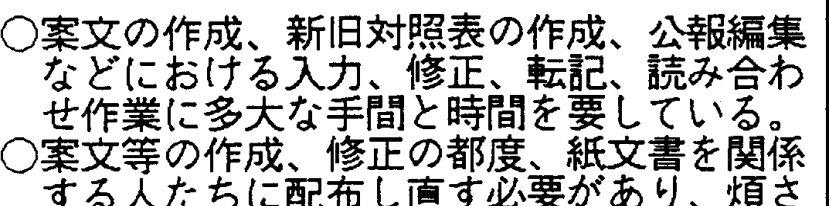 & 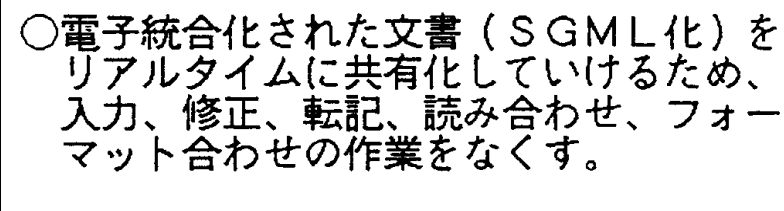 \\
\hline
\end{tabular}

する人たちに配布し直す必要があり、煩さ である。

○関連資料の配布、意見の付与など、相手方 に届けに行く手間がかる。

B) 業務の進行管理がされていない

○業務の手順が人により異なり、手続き無視 が起こりうる。また、どこまで進められた かが担当者以外にはわからない。

C) 法制テクニックに関するスキル低下

○複雑な法制テクニックは、習熟に2〜3年 ○法制テクニックを A | 処理化し、初心者 
を要するが、ひんばんな異動により、全体 のスキルが低下している。
でも直ちに一定レベルの法制業務を行う ことができる。
D）過去の事例の蓄皘・参照が困難

○業務に関連する過去の事例は、案件を検討 して一定の方向を考え出すため最も重要な 情報とされるが、体系的に蓄皘・保存する 手法がなく、活用できない。

\section{過去の事例の容易な活用}

○過去の事例は、すべてデータベースとし て体系的に保存されており、必要な場面 で、面ちに画面上に呼び出し、参照・活 用することができる。
E) 検索もれ、検索時間のムダ

○関連するすべての文言をもれなく拾い出す ことに多くの時間を費やしている。

○例規集は、常に最新状態ではないため、誤 り発生の危険が付きまとう。
フリーワード・リアルタイム・サーチ

○例規集は常に最新状態であり、フリーワ ードにより瞬時にもれなく検索できる。
F ) バラバラで非能率な作業環境

○すべての作業が関連なくバラバラに行われ ており、大変非効率である。

\section{EUC統合環境の提供}

○各課の法制担当者の手元（パソコン）に 法制業務遂行上で必要とされるすべての 支援が集約提供される。

・フリーワード全文検索

·法制テクニックのA|支援

・新旧対照表の自動生成

・過去の改正方法をすぐに参照

・関連セクションとの調整

・その他

\section{3. 法令文への「SGML」の適用と効果に楓する考宾}

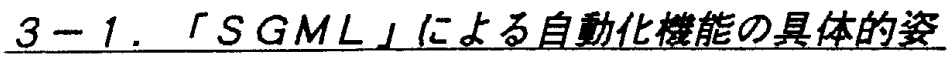

法令文書をSGML化することによる法制業務の具体的姿は、次の画面例（《図表一3 》)に掲げるように、法令文畫がその構造に従って表示され、左側の作業画面に直接改訂 作業を記述することにより行われる。

《図表-3》《作業画面例》

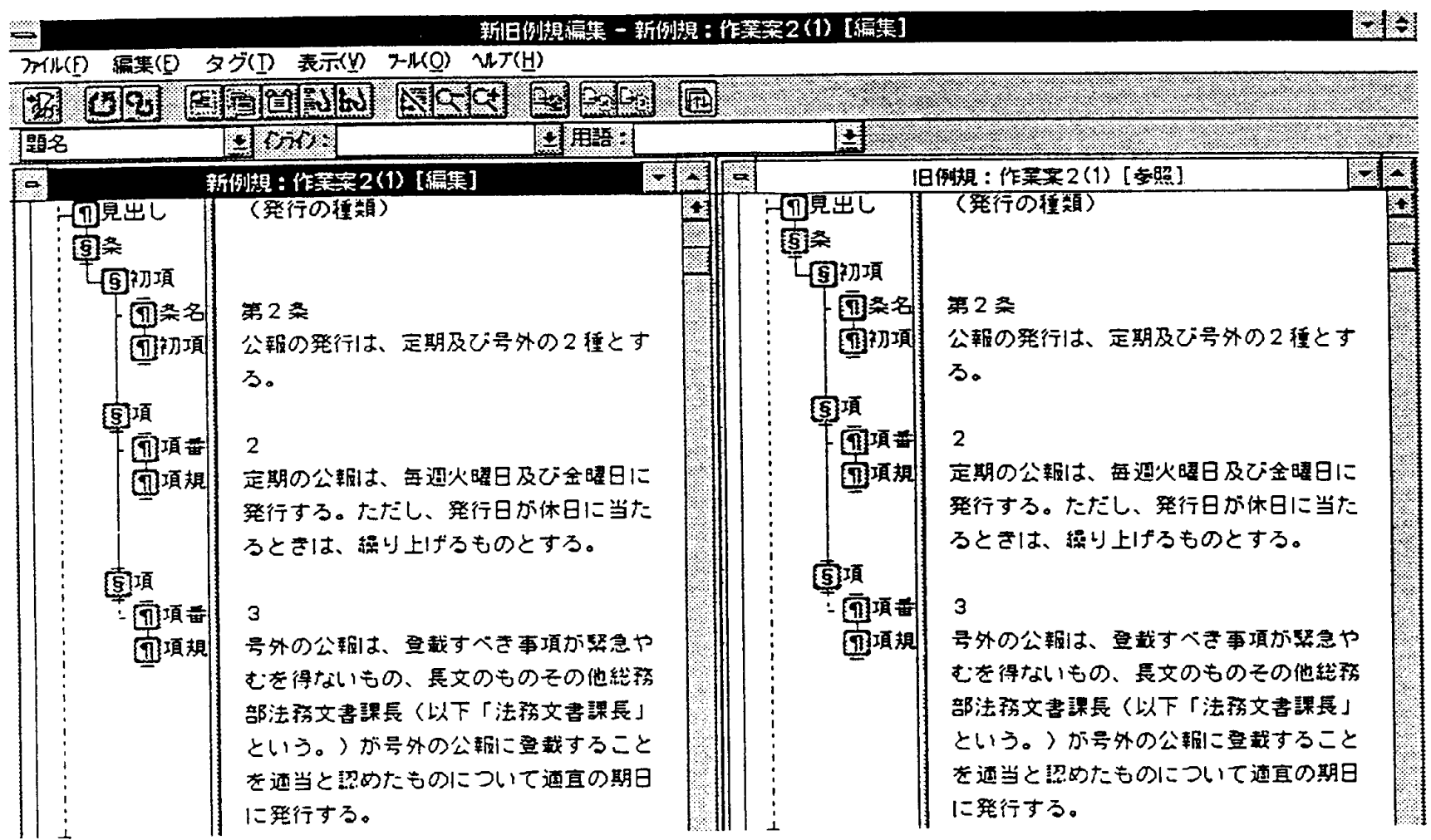


「SGML」がもたらす自動化栱能の具体的姿は、例えば、第2 条第 2 項の「火曜日」 を「水曜日」に改正する場合で説明すると、次のようになる。

ア) 改正入力 =作業者は、左画面でワープロを操作するのと同様に「火」を「水」に直す。

イ）新旧対照表の自動作成

=当硋変更部分の新と旧とを対置して、变更部分にアンダーラインを描いた「新 旧対照表」が自動作成される。

ウ）改正案文の自動作成

=改正案文が、改正文章も、書式もすべて自動的に作成される。

（改正文は『第 2 条第 2 項中「火曜日」を「水曜日」に改める。』）

エ）例規データベースのリアルタイム更新

=公布されれば、指定された施行日に、例規データベースが自動的に更新される。

この例は、極めて単純な改正の場合であり、実際には、後に揭げる公報登載の条例改正 文のように、削除、追加、置換などが入り交じって、大变複雑な改正作業となることがし ばしばである。

そうした複雑な改正の場合にあっても、「SGML」と「日本語形態素解析」技術とを 組み合わせることによって、改正後の規範文書を、誰でもリアルタイムに意味理解が可能 なコンテキストとして読みとることが可能となる。

\section{3ー2. 法令文への「SGML」通用効果に関する考腺}

\section{【規笛文害の特性】}

自治体の行政規範、すなわち、条例、規則、通知などの規程類（以下「規範文畫」とい う)は、論理的、体系的、構造的なスタイルが顕著な文書である。これら構造面からみた 特徵は、次のように整理できる。

ア) 体系性

…章、節など体系的内容が構造的に組み立てられている。

1）立体的入れ子構造性

․メインストリームとサブルーチンとが電算プログラムと同様に、いわゆる「入れ 子構造」をなしている。

ウ)引用權造性

…法令用語という概念の根拠を他の規範を引用することでオーソライズしている。

(例示)

（概念の部品化）

「 000 規則

第○条

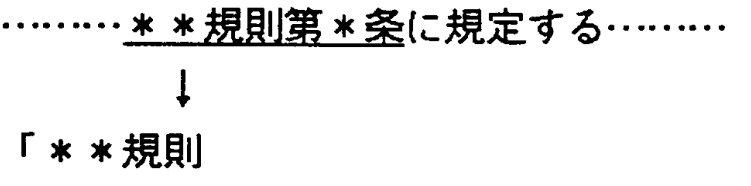

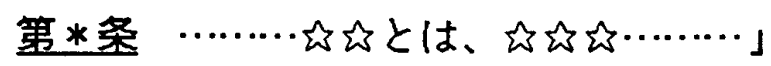

このような構造性を持った規範文書は、元来、外的变化に対応して自らを改变させるこ とを予定したダイナミズムを身に付けているのであるが、特に近年では、科学技術の著し 
い進展に伴い、複雑化した地域社会システムを対象とする自治体の行政規範は、ほとんど 科学技術のマニュアルに近いダイナミックな実態をあらわにしている。その特徴は次のよ うによめられる。

(1) 頻繁な改訂性

科学技術の進展や社会の二ーズに対応し、改訂が頻繁に行われる。

(2) 手続き関与性

施策の多様化に対応し、プロセス制御系が複雑化し、現場の業務手続に詳細に関与 する内容となる。

(3) 相互参照関係性

テクニカルな「部品化」された施策や概念を下数きとして、新たな発展形の施策展 開が進められるので、概念の相互参照が輻輳する。

このような規範文畫のダイナミズムが、時間軸に治って、自らと他との関係性を縦横に 変化させていくとき、一番問題となるのは、その時点その時点毎の、体系的意味概念をコ ンテキストに治って容易に汲み取れること、である。

そこで、規範文書の改正方式である、いわゆる「溶け込み方式」の本質的困難性がクロ 一ズアップされる。

\section{【「溶け込み方式」の困藉性】}

日本における法規範の改正方法は、いわ镸溶け込み方式」によっており、改正後の できあがった姿は、公式な形としては、公表されない。次に例示するごとく、いわば「改 正指示書」のみが公報に登載されているだけである。

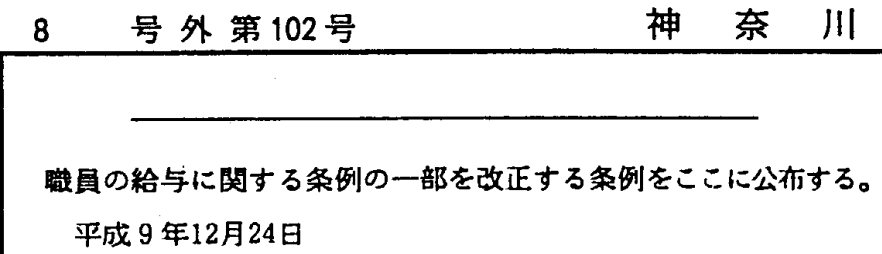

神奈川県条例第 55 号

鞿员の給与に関する条甽の一部を改正する条例

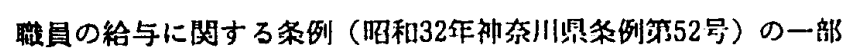
を次のように改正する。

第 7 条の 3 第 1 項第 1 号中 $[21$ 万 8,200 円」 $[22 万 700$ 円に改

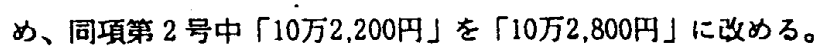

第 8 条第 3 項中「 1 万7,500円」を「 1 万 8.200 円」に、「配保者

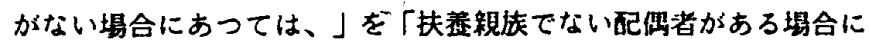
おつてはそのうち1人については6,900円、瀻貝に配仙者がない城 合におつては」に、「1万1,700円」を「1万2,100円」に改め、同 条第 4 項中「4,000円」を†5.000円」に改める。

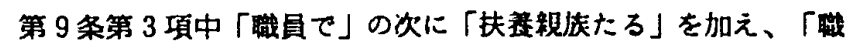

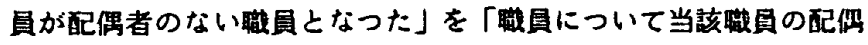
者が扶盖親族たる要件を欠くに至つた場合又は同项第 3 号に掍げる 事実が生じた」に改める。
第14条第 1項中「6,100円」を「6,200円」に、「1万1,400円」を 「1万1,600円」に、「7,000円」を「7,100円」に改める。

第15条第 2 项中「100分の50」を「100分の55」に、「得た積に」

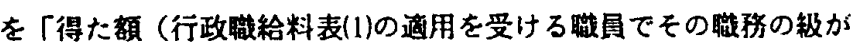
8 級以上であるるの並びに同表以外の各給料表の通用を受ける瞰員 での職務の複雑、困嚾及び責任の度等がこれに相当するもの（人

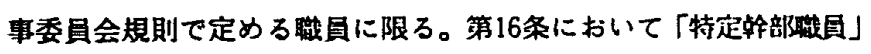
という。）にあつては、3月に支給する場合においては100分の55、 6 月に支給する場合においては1003\}の140、12月に支給する㘯合に おいては100分の170を乘じて得た额）に」に改める。

第16条第 2 項中「100分の60」の次に「(特定垶部職亘にあっては、 1005方の80)」を加える。

別表第 1 から別表第10までを次のように改める。

$$
\text { (以下田各) }
$$


ここで、法制業務のエキスパート以外の一般人が面面する困難な状況としては、

(1) 改正文の䙉雑なテクニックに習熟していないので、改正案文（「改正指示書」） が作れない

（2）「改正指示書」に従って、改正後の法令文章のコンテキストへ溶け込ますことは 言易でない

今「法制業務のエキスパート以外の一般人が面面する困難な状況」と言う表現を用いた が、それでは「法制業務のエキスパート」なら、これらの困難状況は問題とはならないの であろうか。

この問に対する答えは、（1）の困難に関しては、「法制業務のエキスパート」であれば、 相当程度にクリアーできるであろうが、(2) の困難に関しては、場合を分けて説明する必 要がある。

第一に、規範文書改正の担当者は、まず改正後の規範文を作成してから、改正後の状態 を実現するために、「改正指示書」としての改正案文を作成している。従って、コンテキ スト理解が前提となっている。

第二に、当該担当者以外の「法制業務のエキスパート」にとっては、改正後の規範文を 必ずしも入手できるわけではないので、意味を読み解くには、慣れによる理解の早さはあ っても、本質的に一般人と同様の困難が存在する。

以上、「溶け込み方式」の困難性をめぐって述べたことを、次の模式図のように表現し てみた。

\section{《図表一4》《規範文書の改正作業と意味概念に関する模式図 》}

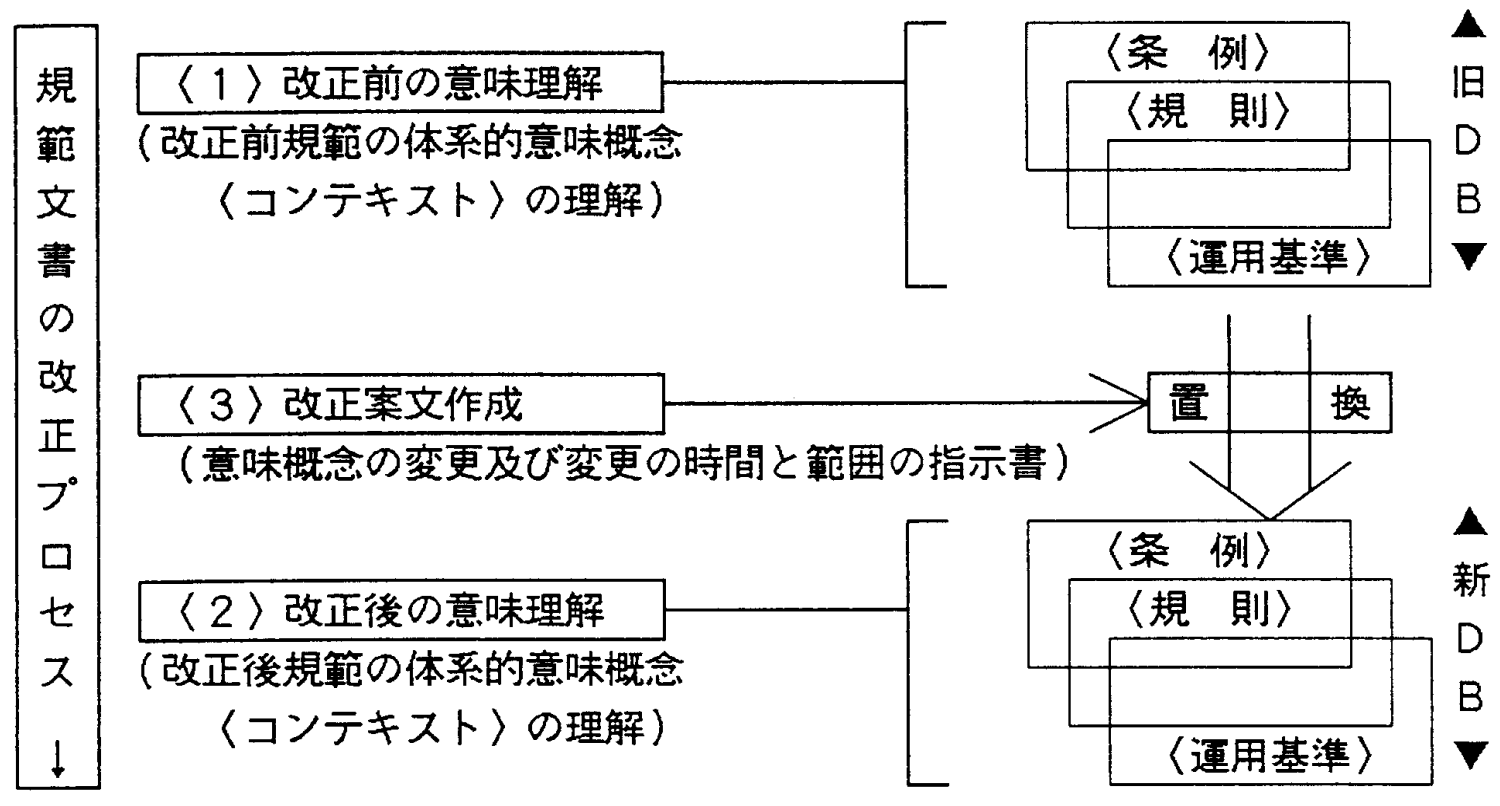

模式図から明らかなように、「改正案文作成」は、「改正前の意味理解」すなおち、改 正前の規範たる条例、規則及び運用基隼などのコンテキストをたどることによって、その 時点における体系的意味概念を立体的に理解することから始まり、次に、「改正後の意味 理解」すなわち、自ら改正を行おうとする改正後の条例、規則及び運用基準など規範の仕 上がりの姿を描きながら、コンテキストをたどることによって、それら規範群の体系的意 味概念を立体的に理解した上で、「改正案文作成」すなわち、変更箇所の指示書を作成す 
るに至る。

このように、規範の改正とは、意味概念の変更及び変更の時間と範囲の指示のことであ り、先に見たように、今日の裇合的な社会システムでは、概念の部品化、読み替え等の複 雑な構造性を持っているが故に、常に、全体として意味の読みとれるコンテキストとして 復元されていなければ、その意味理解はほとんど不能な状況にある。

今日、行政改革の最大の課題は、政策の「評価」であると言われている。そして、規範 とは、政策（施策）内容を意味概念として表象したものである。分権時代の地域の自己決 定権の現れとしての自治体規範であってみれば、すなわち、「政策評価」の前提として、 規範の意味概念の十分な理解は、行政改革を実体あらしめる上で不可欠といえる。

ここで問題は、「評価」できるまで物事をわかりやすい姿へと集約、整理、変換してい くコスト、労力をどのように縮減するか、である。これまで「数值情報」についてはシミ ユレーション技法の発達により、集約、整理、変換を容易にこなしてきた。今後は、いよ いよ「言語情報」についても、「垀価」の前提としての意味理解を容易にする一種のシミ ユレーション技法が求められる。「SGML」には、「日本語形態素解析」技術等のA I 技術と組み合わせることによって、複合的な言語の意味理解をシミュレートする椫能が、 大きな役割として期待されている。

4. まとめ

インターネットの流行と広範な活用の進展を背景としてか、電子文書管理、ないしは文 書の電子化というテーマが、このところ急速に関心を集めつつある。これまでの物理的な ペーパー文書の取り扱いにおける桎梏、とりわけ、大量の文書情報の保存、検索における 時間·空間上の多大な労力をほとんどゼロに近づけ、いとも簡単に、かつ縦横に中身の情 報にたどり着けるということが実感されてきたからであろう。

しかるに、こうした「電子文書」化への動向が、高度情報化社会といわれる非常に発達 した高度な科学技術文明下における社会システムのあり方に、どのように関係付けられて いくのかという、より本質的なアプローチに関しては、必ずしも明らかにされてはいない と思われる。

すなわち、「CALS」に代表される産業社会の組織業務の効率的運営方法や、地域課 題に真に貢献できる政策推進を図るための広義の「行政改革」などの、大变重要な社会の イノベーションへ向け、「電子文書」化がもたらす本質的影響と、その中で「SGML」 ないしは「XML」が果たす根元的機能に正面から言及し、かつ広めようとする動向は、 論者の知る限り、大变弱いと思われる。

この短い稿では、「SGML」をベースとした「電子文書」化がもたらすイノベーティ ブな意義について、『組織業務の効率的改革』及び『アカウンタビリティーへ向けた意味 概念の共有化』というニつの面から、アプローチを試みた。 
情報知識学会誌 Vol.8 No.2

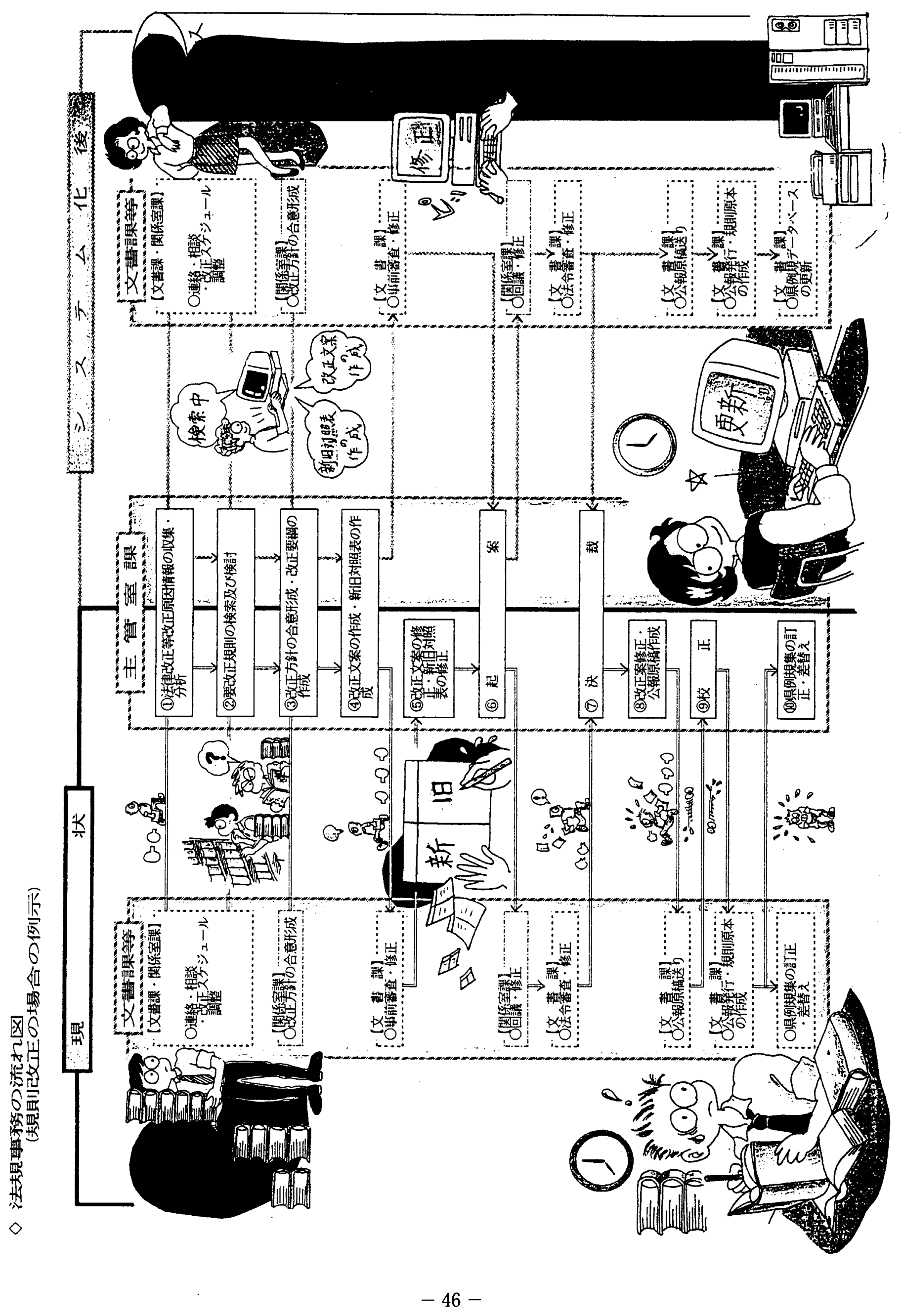

